\title{
Comparisons of Holsteins with Brown Swiss and Jersey Cows on the Same Farm for Age at First Calving and First Calving Interval
}

\author{
T. B. Garcia-Peniche, ${ }^{1}$ B. G. Cassell, ${ }^{1}$ R. E. Pearson, ${ }^{1}$ and I. Misztal ${ }^{2}$ \\ ${ }^{1}$ Department of Dairy Science, \\ Virginia Polytechnic Institute and State University, Blacksburg 24061 \\ ${ }^{2}$ Department of Animal and Dairy Science, University of Georgia, Athens 30602
}

\section{ABSTRACT}

Our objective was to evaluate breed differences for heat-stress resistance as reflected by age at first calving and first calving interval. We examined the effect of geographic location and birth season on age at first calving, and geographic location and first calving season on first calving interval on Holsteins and Jerseys, and Holsteins and Brown Swiss located on the same farm. We defined 7 regions within the United States: Northwest, Central north, Northeast, Central, Central south, Southwest, and Southeast, and analyzed 7 individual states: Ohio, Wisconsin, Oregon, California, Arizona, Texas, and Florida. Brown Swiss were older than Holsteins at first calving $(833 \pm 2.4$ vs. $806 \pm 2.0 \mathrm{~d}$ in regions, and $830 \pm 3.1$ vs. $803 \pm 2.4 \mathrm{~d}$ in states), but Holsteins and Brown Swiss did not differ for first calving interval. Jerseys were younger than Holsteins at first calving and had shorter first calving intervals. In data from individual states, Holsteins housed with Brown Swiss were older at first calving than were Holsteins housed with Jerseys $(800 \pm 2.7$ vs. $780 \pm 2.5$ d). Holsteins housed with one breed or the other were analyzed as a separate data set, and referred to as "type of Holstein." The interaction of "type of Holstein" with first calving season was highly significant for first calving interval. Geographic location and season effects were smaller for Jerseys than for Holsteins; thus, Jerseys showed evidence of heat-stress resistance with respect to Holsteins. Management modified age at first calving in Holsteins to more nearly match that of the other breed. Longer calving intervals might be partly due to voluntary waiting period to breed the cows.

(Key words: breed comparison, age at first calving, first calving interval, heat-stress resistance)

Abbreviation key: AFC = age at first calving, FCI = first calving interval, $\mathbf{H B}=$ farms with Holsteins and Brown Swiss, HJ = farms with Holsteins and Jerseys.

Received June 15, 2004.

Accepted October 12, 2004.

Corresponding author: B. G. Cassell; e-mail: bcassell@vt.edu.

\section{INTRODUCTION}

Fertility in cows of all dairy breeds has diminished over time in the United States (VanRaden et al., 2003). Lopez-Gatius (2003) reported a similar fertility trend for Holstein cows in Northeastern Spain, but fertility was most affected under heat stress conditions at breeding. Heat stress disrupts reproduction in dairy cattle (Kadzere et al., 2002), and is a known problem in regions with warm or hot climates, especially if ambient humidity is also high. The United States has been subjectively partitioned to account for regional differences in production, reproduction, and health traits for genetic evaluations (Wiggans and VanRaden, 1991; Norman et al., 1995, 2000; Oseni et al., 2003; VanRaden et al., 2003; Zwald et al., 2003). VanRaden et al. (2003) divided the country into 5 regions for USDA evaluations of daughter pregnancy rates, and noted that the main differences in days open by month of calving occurred in the Southeast. Zwald et al. (2003) used a similar division for sire evaluations, but divided the Midwest and Southeast into Central north, Central, Central south, and Southeast regions. Cattle in these regions are likely to be subject to little heat stress year-round (Central north), heat stress during summers only (Central), heat stress with low humidity (Central south), and heat stress with high humidity (Southeast) (D. A. Wert, National Weather Service, Blacksburg, VA, 2004, personal communication).

Seasonal heat stress may have an impact on reproductive performance even in temperate regions. For example, Alnimer et al. (2002) found that pregnancy rate was higher for cows inseminated in winter (average daily ambient temperature of $10.9^{\circ} \mathrm{C}$ ) than in summer (average daily ambient temperature of $20.2^{\circ} \mathrm{C}$ ) using Italian data. The season of birth of the cow can affect milk production (Barash et al., 1996). Season of birth could also affect age at first calving (AFC) because energy requirements of the calf to maintain thermoneutrality increase with heat stress. At the same time, DMI diminishes. Such effects could delay onset of puberty and increase AFC (Fox and Tylutki, 1998). The effect of birth season on first calving interval (FCI) has not been reported. 
Table 1. Numbers of cows and herds in the Holstein-Brown Swiss datasets for analyses by region and state.

\begin{tabular}{|c|c|c|c|c|c|c|c|}
\hline \multirow[b]{2}{*}{ Regions } & \multicolumn{2}{|c|}{ Cows } & \multirow[b]{2}{*}{$\begin{array}{l}\text { No. of } \\
\text { herds }\end{array}$} & \multirow[b]{2}{*}{ States } & \multicolumn{2}{|c|}{ Cows } & \multirow[b]{2}{*}{$\begin{array}{l}\text { No. of } \\
\text { herds }\end{array}$} \\
\hline & Holstein & $\begin{array}{l}\text { Brown } \\
\text { Swiss }\end{array}$ & & & Holstein & $\begin{array}{l}\text { Brown } \\
\text { Swiss }\end{array}$ & \\
\hline Northwest & 467 & 141 & 8 & Ohio & 131 & 75 & 5 \\
\hline Central north & 867 & 520 & 47 & Wisconsin & 234 & 211 & 18 \\
\hline Northeast & 490 & 191 & 33 & Oregon & 344 & 109 & 3 \\
\hline Central & 544 & 261 & 28 & California & 904 & 174 & 8 \\
\hline Central south & 298 & 291 & 8 & Arizona & 2068 & 347 & 4 \\
\hline Southeast & 152 & 67 & 10 & Texas & 282 & 285 & 6 \\
\hline Southwest & 3335 & 649 & 16 & Florida & 98 & 31 & 2 \\
\hline
\end{tabular}

Age at first calving and FCI impact profitability (Tozer and Heinrichs, 2001), but AFC has not been widely studied, even though there is evidence that it influences milk production and survivability (Durr et al., 1999). Rajala-Schultz and Frazer (2003), using data from Ohio, found that days from calving to conception increased in cows from 1992 to 1998, but remained stable for heifers. Age at first calving and FCI can be used to evaluate reproductive performance under heat stress.

Comparison of breeds for fertility is justified at an intraherd level because reproductive traits are highly influenced by management (Castillo-Juárez et al., 2000). In this study we used only farms with 2 breeds of cows, i.e., farms with Holsteins and Jerseys (HJ) and farms with Holsteins and Brown Swiss (HB).

The objective of this study was to evaluate breed differences for heat stress resistance by analyzing the effects of geographic location and birth season on AFC and the effects of geographic location and season of first calving on FCI on Holsteins and Jerseys, and Holsteins and Brown Swiss housed in the same farm. The United States was partitioned into 7 regions, and 7 states were studied individually for geographic location effects. Similar climatic conditions were assumed within regions or states, and cows of different breeds in the same farm were assumed to face the same environmental conditions.

\section{MATERIALS AND METHODS}

The USDA Animal Improvement Programs Laboratory provided data consisting of records with calvings from January 1, 1995 to June 30, 2001. Data from Brown Swiss and Jersey cows were merged with Holstein data when they had the same DHI herd codes. We also merged Brown Swiss or Jersey with Holstein cows when herd codes were different, but the farm address was the same. Two data sets resulted: one with HJ and one with HB farms.

The majority of the farms with 2 breeds had only a few cows of one of the breeds. For such farms, breed, region, and season effects would be poorly estimated. Herd-year-season breed groups of 3 or more cows were required, but most of the farms included had more cows of each breed. Study of FCI requires cows that survive to calve a second time, whereas AFC only requires that cows calve once. In this study we used the same cows for both traits. The impact of requiring a second calving on AFC is unknown. The data used were restricted to cows with their first 2 calvings on the same farm with at least $310 \mathrm{~d}$ between calvings. Before edits, the data included 178,090 cows in 1387 herds with Holsteins and Brown Swiss with at least 5 cows per breed. These farms had only 5.2\% Brown Swiss cows. After edits, records from 8273 cows in $150 \mathrm{HB}$ farms remained, with $25.6 \%$ of the records from Brown Swiss cows. There were 222,528 cows in $2117 \mathrm{HJ}$ farms with $12.8 \%$ of Jersey cows before edits, and 17,492 cows in 219 farms with $38.2 \%$ Jerseys after edits.

In a preliminary study, we fitted birth season and birth year for analysis of FCI. We found that birth season did influence FCI, but through an indirect relationship to season of first calving. Season of birth influenced insemination season, but conception season determined calving season. We chose to report only the effect of first calving season on FCI.

The states included in this study from the 7 regions of Zwald, et al. (2003) were:

1. Northwest: Idaho, Washington, and Oregon,

2. Central north: Michigan, Wisconsin, Iowa, Minnesota, and South Dakota,

3. Northeast: Connecticut, Maine, Massachusetts, New Hampshire, New York, Pennsylvania, Delaware, Maryland, and Vermont,

4. Central: Ohio, Indiana, Illinois, Kansas, Nebraska, Missouri, Kentucky, Tennessee, Virginia, and West Virginia,

5. Central south: Texas, Oklahoma, and Louisiana,

6. Southeast: Florida, Georgia, South Carolina, North Carolina, Alabama, Mississippi, and Puerto Rico.

7. Southwest: Colorado, New Mexico, Arizona, Utah, and California. 
Table 2. Numbers of cows and herds in the Holstein-Jersey datasets for analyses by region and state.

\begin{tabular}{|c|c|c|c|c|c|c|c|}
\hline \multirow[b]{2}{*}{ Regions } & \multicolumn{2}{|c|}{ Cows } & \multirow{2}{*}{$\begin{array}{l}\text { No. of } \\
\text { herds }\end{array}$} & \multirow[b]{2}{*}{ States } & \multicolumn{2}{|c|}{ Cows } & \multirow{2}{*}{$\begin{array}{l}\text { No. of } \\
\text { herds }\end{array}$} \\
\hline & Holstein & Jersey & & & Holstein & Jersey & \\
\hline Northwest & 1384 & 370 & 19 & Ohio & 123 & 96 & 6 \\
\hline Central north & 501 & 334 & 29 & Wisconsin & 161 & 86 & 12 \\
\hline Northeast & 1181 & 546 & 59 & Oregon & 416 & 231 & 13 \\
\hline Central & 964 & 517 & 32 & California & 4513 & 2095 & 34 \\
\hline Central south & 312 & 243 & 14 & Arizona & 713 & 1829 & 2 \\
\hline Southeast & 955 & 585 & 22 & Texas & 209 & 129 & 10 \\
\hline Southwest & 5518 & 4082 & 44 & Florida & 435 & 204 & 4 \\
\hline
\end{tabular}

Seven states were analyzed separately for each data set: Wisconsin, Ohio, Oregon, California, Arizona, Texas, and Florida. These states were chosen because they have temperate, warm-humid, and warm-dry climates, and both types of farms, i.e., HB and HJ, with reasonable numbers of Brown Swiss and Jerseys, and contained about $64 \%$ of the data. The number of herds and cows per region and state are presented in Tables 1 and 2 , respectively.

Analyses were performed on each breed combination data set separately. The model was:

$$
\begin{gathered}
\mathrm{Y}_{\mathrm{ijk} l m n}=\mu+\mathrm{b}_{\mathrm{i}}+\mathrm{r}_{\mathrm{j}}+\mathrm{s}_{\mathrm{k}}+\mathrm{br}_{\mathrm{ij}} \\
+\mathrm{bs}_{\mathrm{ik}}+\mathrm{yr}_{\mathrm{l}}+\mathrm{h}(\mathrm{r})_{\mathrm{m}}+\varepsilon_{\mathrm{ijklmn}}
\end{gathered}
$$

where $\mathrm{Y}=$ age at first calving or FCI, $\mu=$ the general mean, $b=$ breed, i.e., either Holstein and Brown Swiss, or Holstein and Jersey, $\mathrm{r}=$ geographic location, i.e., either regions or states, $\mathrm{s}=$ birth season of the cow when analyzing AFC, or first calving season, when analyzing FCI. Seasons were defined as spring (March-May); summer (June-August); fall (September-November), and winter (December-February), yr = year of birth of the cow for the analysis of AFC, or year of first calving for the analysis of FCI, $\mathrm{h}=$ herd, nested in $\mathrm{r}$, and $\varepsilon=$ the residual, assumed $\sim \mathrm{N}\left(0, \sigma^{2}\right)$.

An additional data set with Holsteins from both types of farms was created and analyzed for the states with the same model, but with herd nested in state by "type of Holstein" (Holsteins in HJ farms and Holsteins in HB farms).

Data were analyzed using the MIXED procedure in SAS (SAS Institute, 1999), with the probability differences between least square means tested using the Tukey-Kramer option.

\section{RESULTS}

General $P$ values of the analyses are mentioned at the beginning of each section. The specific probability differences between breeds, within regions or states, and within seasons are presented in Tables 3 to 8 . The
$P$ values obtained between regions or seasons, within breeds, are mentioned when appropriate.

\section{Holstein and Brown Swiss}

Age at first calving. In the analysis by regions, breed, geographic location, and the interaction of breed by geographic location were significant $(P<0.01)$. Birth season was not significant $(P=0.11)$, but breed by birth season $(P=0.01)$ was. In the analysis by states, all the effects were highly significant $(P<0.01)$. At first calving, Brown Swiss were older than Holsteins. Table 3 shows that breed differences were not significant in the Northwest, the Southeast or for the herds in Oregon, Arizona, and Florida. Table 4 shows that Brown Swiss were 18 to 25 d older for AFC than Holsteins for birth seasons other than fall. For cows born in fall, the differences between breeds were $36 \mathrm{~d}$ in regions and $43 \mathrm{~d}$ in the states, making the interaction of breed by birth season significant.

First calving interval. In the analysis by regions, the effects of geographic location and first calving season were highly significant $(P<0.01)$. The maximum FCI occurred in the Southeast and when cows calved in spring, and the minimum in the Southwest and when cows calved in fall. Breed and the interactions of breed by region were not significant. Breed difference approached significance in the Southeast $(P=0.08)$, with $22 \mathrm{~d}$ shorter FCI for Brown Swiss than for Holsteins $(464 \pm 9.0 \mathrm{~d}$ for Holsteins vs. $442 \pm 10.8 \mathrm{~d}$ for Brown Swiss). In the analysis by states, the effects of geographic location $(P<0.01)$, first calving season $(P<$ 0.01 ), and the interaction of breed by first calving season $(P<0.01)$ were significant. The shorter FCI of Brown Swiss relative to Holsteins approached significance for cows first calving in summer $(P=0.07)$, and in Florida $(P=0.09)$, with Brown Swiss having $27 \mathrm{~d}$ shorter FCI than Holsteins ( $436 \pm 10.0$ vs. $409 \pm 15.8$ d).

\section{Holstein and Jersey}

Age at first calving. In the analysis by regions, all the effects were significant $(P<0.01)$ except breed by 
Table 3. Least squares means (SE) of age at first calving for breed by geographic location in HolsteinBrown Swiss herds in 7 regions and 7 states.

\begin{tabular}{lllllllr}
\hline Regions & Holstein & \multicolumn{1}{l}{$\begin{array}{l}\text { Brown } \\
\text { Swiss }\end{array}$} & \multicolumn{1}{c}{$P^{1}$} & State & Holstein & \multicolumn{1}{l}{ Brown } \\
Swiss & $P^{1}$ \\
\hline Northwest & $795(5.0)$ & $809(7.1)$ & 0.75 & Ohio & $791(9.9)$ & $829(10.8)$ & $<0.01$ \\
Central north & $803(3.3)$ & $838(3.6)$ & $<0.01$ & Wisconsin & $800(5.2)$ & $822(13.0)$ & $<0.01$ \\
Northeast & $802(4.3)$ & $832(5.3)$ & $<0.01$ & Oregon & $815(4.6)$ & $831(7.1)$ & 0.65 \\
Central & $801(4.2)$ & $847(4.8)$ & $<0.01$ & California & $820(4.3)$ & $862(5.9)$ & $<0.01$ \\
Central south & $809(5.7)$ & $835(6.5)$ & $<0.01$ & Arizona & $780(1.8)$ & $792(3.6)$ & 0.19 \\
Southeast & $819(7.6)$ & $834(9.2)$ & 0.96 & Texas & $811(4.9)$ & $836(5.7)$ & $<0.01$ \\
Southwest & $812(2.7)$ & $833(3.6)$ & $<0.01$ & Florida & $801(8.2)$ & $822(13)$ & 0.96 \\
\hline
\end{tabular}

${ }^{1} P$ values defining the significance of difference between least squares means of breed, by region or state, using Tukey-Kramer tests.

geographic location $(P=0.07)$. Jerseys were younger than Holsteins at first calving in all regions. The differences were significant in the Central $(P=0.04)$, Central south $(P<0.01)$, and Southeast regions $(P=0.02)$; all of which are areas where heat stress is more likely. In the analysis by states, all the effects were highly significant $(P<0.01)$. Jerseys were younger at first calving than Holsteins in all states, except in Arizona, but the differences were only significant for the herds in Wisconsin $(P=0.03)$, California $(P=0.03)$, and Florida $(P=0.02)$. Table 5 shows that Jerseys were younger than Holsteins for all birth seasons in regions and states. Differences between breeds were significant $(P$ $<0.01$ ) for cows born in summer (regional data) or born in summer and fall (state data).

First calving interval. For the analysis by regions, all the effects were highly significant $(P<0.01)$. Jerseys had shorter FCI than Holsteins in all the breed comparisons in this study (Tables 6 and 7). Table 6 shows that the differences between Holsteins and Jerseys were largest in the Central south ( $35 \mathrm{~d}$ ) and Southeast (26 d), when Holsteins increased FCI more than Jerseys. First calving interval was longest for both breeds in Central south. For the analysis by states, the effects of breed, geographic location, and first calving season were highly significant $(P<0.01)$, as well as the interaction of breed by first calving season $(P=0.02)$. Only the interaction of breed by geographic location was not significant $(P=0.12)$. However, differences between Holsteins and Jerseys were significant for California, Florida, and Texas $(P<0.01)$, and approached significance $(P=0.06)$ for Arizona (Table 6$)$. These cattle in these 4 states were more likely to have experienced heat stress at some point than the cows in the other 3 states. Jerseys had significantly shorter FCI than Holsteins for all first calving seasons in the analysis by regions, and for spring, summer, and winter in the analysis by states (Table 7).

\section{Holsteins Housed with Brown Swiss and Holsteins Housed with Jerseys}

We merged data from individual states from Holsteins housed with Brown Swiss and Holsteins housed with Jerseys to see if Holsteins performed similarly when managed with different breeds. For AFC, the effect of "type of Holstein" and the interaction of "type of Holstein" with birth season were highly significant ( $P$ $<0.01$ ). Holsteins housed with Brown Swiss calved for the first time at older ages than did Holsteins housed with Jerseys $(800 \pm 2.7$ vs. $780 \pm 2.5$ d, respectively). Table 8 shows that the maximum difference occurred in Arizona (46 d) and the minimum in Texas ( $2 \mathrm{~d}$ ).

Holsteins housed with Jerseys usually had about a week shorter FCI than did Holsteins with Brown Swiss, but the differences between "types of Holstein" were

Table 4. Least squares means (SE) of age at first calving for breed by birth season in Holstein-Brown Swiss herds in 7 regions and 7 states.

\begin{tabular}{llllllll}
\hline & \multicolumn{3}{c}{ In regions } & & \multicolumn{3}{c}{ In states } \\
\cline { 2 - 3 } Birth season & Holstein & $\begin{array}{l}\text { Brown } \\
\text { Swiss }\end{array}$ & $P^{1}$ & & Holstein & Brown \\
Swiss & $P^{1}$ \\
\hline Spring & $805(2.7)$ & $829(3.6)$ & $<0.01$ & & $806(3.2)$ & $824(4.5)$ & $<0.01$ \\
Summer & $807(2.6)$ & $829(3.4)$ & $<0.01$ & & $801(3.1)$ & $825(4.3)$ & $<0.01$ \\
Fall & $802(2.4)$ & $838(3.4)$ & $<0.01$ & & $796(2.9)$ & $839(4.4)$ & $<0.01$ \\
Winter & $811(2.5)$ & $835(3.7)$ & $<0.01$ & $810(2.9)$ & $835(4.5)$ & $<0.01$ \\
\hline
\end{tabular}

${ }^{1} P$ values defining the significance of difference between least squares means of breed, by birth season in regions or states, using Tukey-Kramer tests. 
Table 5. Least squares means (SE) of age at first calving for breed by birth season in Holstein-Jersey herds in 7 regions and 7 states.

\begin{tabular}{lllllllr}
\hline & \multicolumn{3}{c}{ In regions } & & \multicolumn{3}{c}{ In states } \\
\cline { 2 - 3 } Birth season & Holstein & Jersey & \multicolumn{1}{c}{$P^{1}$} & & Holstein & Jersey & \multicolumn{1}{c}{$P^{1}$} \\
\hline Spring & $814(2.0)$ & $806(2.3)$ & 0.07 & & $782(2.8)$ & $781(3.1)$ & 0.99 \\
Summer & $812(1.9)$ & $797(2.2)$ & $<0.01$ & & $788(2.9)$ & $775(3.1)$ & $<0.01$ \\
Fall & $803(1.8)$ & $797(2.1)$ & 0.23 & & $784(2.8)$ & $772(3.1)$ & $<0.01$ \\
Winter & $811(1.9)$ & $809(2.8)$ & 0.45 & & $787(2.8)$ & $784(3.1)$ & 0.98 \\
\hline
\end{tabular}

${ }^{1} P$ values defining the significance of difference between least squares means of breed, by birth season in regions or states, using Tukey-Kramer tests.

not significant. The interaction of "type of Holstein" with first calving season was highly significant $(P<$ 0.01). The interaction occurred because Holsteins with Brown Swiss had shorter FCI for the herds in Florida (2 d) and Wisconsin (14 d) than Holsteins with Jerseys.

\section{DISCUSSION}

Fox and Tylutki (1998) predicted increased AFC in environments with heat stress. Our study showed variable results for the Southern regions. These differences were probably due to the size of the dairy herds, different management systems, and to true breed differences. Jerseys can reach the minimum required weight for insemination at younger ages than other breeds (Badinga et al., 1985; Ruvuna et al., 1986; Graves, 2003). We observed this result mainly in the southern regions, suggesting heat-stress resistance for Jerseys with respect to Holsteins. Jerseys were significantly younger than Holsteins at first calving when they were born in spring, summer, and fall, again suggesting heat-stress resistance for Jerseys.

We also observed evidence of heat-stress resistance for Jerseys compared with Holsteins for FCI, as the difference between breeds was greater in the southern areas of the country. Our results agree with VanRaden et al. (2003), who found that Jerseys had higher pregnancy rates than Holsteins or Brown Swiss. Our results are also in accordance with Ruvuna et al. (1983), who reported longer days open for Holsteins than for Brown Swiss or Jerseys or their crosses, particularly in the warm season. Badinga et al. (1985) compared Holsteins, Brown Swiss, and Jerseys and found higher conception rates and fewer services per conception for Jerseys in Florida. Campos et al. (1994) reported higher fertility for Jerseys than for Holsteins in Florida.

Correa-Calderón et al. (2004) concluded that Brown Swiss showed evidence of heat-stress resistance when compared with Holsteins. In our results, Brown Swiss were older at first calving than Holsteins, regardless of region or season. This may be for a reason other than lack of heat-stress resistance. Pirlo et al. (2000) reported average AFC of 995 d from 1972 to 1995 for Brown Swiss in Italy, which is much higher than in the present study. Older AFC for Brown Swiss could be due to rate of maturity, independent of heat-stress resistance. Perhaps the genetic capability of Brown Swiss and management decisions could be confounded, as Brown Swiss have been reported to grow as fast as Holsteins (Ruvuna et al., 1986). Management effects must be important for AFC, because differences between Holstein and Brown Swiss were maximal in California (42 d) and minimal in Arizona (12 d). Brown Swiss had shorter FCI than Holsteins in the regions most likely to produce heat stress, but the differences were not significant. Possibly the small numbers of Brown Swiss reduced our ability to detect significant differences.

Table 6. Least squares means (SE) of first calving interval for breed by geographic location in HolsteinJersey herds in 7 regions and 7 states.

\begin{tabular}{lllrlllr}
\hline Region & Holstein & Jersey & \multicolumn{1}{c}{$P^{1}$} & State & Holstein & Jersey & \multicolumn{1}{c}{$P^{1}$} \\
\hline Northwest & $414(4.7)$ & $400(5.1)$ & 0.15 & Ohio & $421(9.0)$ & $405(9.6)$ & 0.95 \\
Central north & $414(4.7)$ & $390(5.1)$ & $<0.01$ & Wisconsin & $394(7.7)$ & $383(8.5)$ & 0.99 \\
Northeast & $409(3.4)$ & $399(3.8)$ & 0.71 & Oregon & $407(5.7)$ & $404(6.2)$ & 0.99 \\
Central & $423(3.7)$ & $402(4.1)$ & $<0.01$ & California & $403(2.6)$ & $395(2.9)$ & 0.01 \\
Central south & $461(4.9)$ & $426(5.6)$ & $<0.01$ & Arizona & $401(9.1)$ & $390(9.1)$ & 0.06 \\
Southeast & $439(3.9)$ & $413(4.3)$ & $<0.01$ & Texas & $461(5.8)$ & $432(7.1)$ & $<0.01$ \\
Southwest & $408(2.3)$ & $397(2.5)$ & $<0.01$ & Florida & $446(4.2)$ & $424(5.6)$ & $<0.01$ \\
\hline
\end{tabular}

${ }^{1} P$ values defining the significance of difference between least squares means of breed, by region or state, using Tukey-Kramer tests. 
Table 7. Least squares means (SE) of first calving interval for breed by first calving season in HolsteinJersey herds in 7 regions and 7 states.

\begin{tabular}{lllllllr}
\hline & \multicolumn{3}{c}{ In regions } & & \multicolumn{3}{c}{ In states } \\
\cline { 2 - 3 } First calving season & Holstein & Jerseys & $P^{1}$ & & Holstein & Jerseys & $P^{1}$ \\
\hline Spring & $424(2.0)$ & $401(2.3)$ & $<0.01$ & & $418(2.9)$ & $397(3.1)$ & $<0.01$ \\
Summer & $421(2.5)$ & $402(2.7)$ & $<0.01$ & & $417(3.3)$ & $402(3.5)$ & $<0.01$ \\
Fall & $424(1.9)$ & $410(2.2)$ & $<0.01$ & & $423(3.0)$ & $415(3.5)$ & 0.45 \\
Winter & $427(2.2)$ & $402(2.6)$ & $<0.01$ & & $417(3.0)$ & $404(3.4)$ & 0.01 \\
\hline
\end{tabular}

The Southwest included the largest number of cows of all regions for both HJ and HB herds. For the Southwest, AFC and FCI for both pairs of breeds were similar to northern regions, suggesting effective implementation of heat abatement procedures. Ray et al. (1992) reported that management practices had improved in Arizona. This state had the lowest AFC and FCI in both types of farms. Cooling techniques that involve sprinklers and fans are more effective in dry than in humid conditions and could be successfully used in Arizona.

Fertility is curtailed under heat stress (Jonsson et al., 1997; Kadzere et al., 2002) and insemination dates are influenced by calving dates. In frequency analyses not shown, we found that most first calvings occurred during the fall, followed by spring or winter, depending on region. Apparently the season to avoid for calvings was summer, especially for the southern regions. VanRaden et al. (2003), in a study of regional effects on days open in Holsteins, showed that days open fluctuate more across months of calving in the Southeast than in the other regions. Thus for some months, days open in the Southeast is lower than in any other region. This result indicates beneficial effects of voluntary management of days open (Oseni et al., 2003), and as a consequence, of calving interval. Larger standard errors in regions or states most likely to produce heat stress were partly due to relatively low numbers of cows and to

Table 8. Least squares means (SE) of age at first calving for Holsteins housed with Brown Swiss (HB) or with Jerseys (HJ) in 7 states.

\begin{tabular}{lllr}
\hline & HB Holsteins & HJ Holsteins & \multicolumn{1}{c}{$P^{1}$} \\
\hline Ohio & $775(11.9)$ & $759(8.9)$ & 0.99 \\
Wisconsin & $802(6.0)$ & $775(1.3)$ & 0.16 \\
Oregon & $815(4.8)$ & $808(5.7)$ & 0.99 \\
California & $818(5.4)$ & $801(3.1)$ & 0.08 \\
Arizona & $780(1.8)$ & $734(8.4)$ & $<0.01$ \\
Texas & $806(5.6)$ & $804(5.3)$ & 0.99 \\
Florida & $801(8.2)$ & $776(3.5)$ & 0.26 \\
\hline
\end{tabular}

${ }^{1} P$ values defining the significance of difference between least squares means of type of Holstein, by state, using Tukey-Kramer tests. seasonality of first calving seasons, and thus, of insemination seasons.

Both types of farms ( $\mathrm{HB}$ and $\mathrm{HJ}$ ) were in each of the individual states analyzed. Thus, the differential behavior of Holsteins when paired with Brown Swiss or Jerseys was not the result of unequal distribution of the 2 types of farms throughout the country, but from homogenizing management decisions. Holsteins behaved like the breed with which they were paired, even when FCI was not significantly different between Holsteins from the 2 types of farms.

This study was concerned with breed differences for AFC and FCI, regardless of production level, pedigree quality, or the influence of other traits. Our purpose was to compare the behavior of 2 breeds per data set when they were subject to similar management decisions, under similar environmental conditions. Farms with relatively large numbers of cows of 2 breeds are rare in this country, but they are useful to study breed differences in routine management conditions.

\section{CONCLUSIONS}

Jerseys and, to a lesser extent, Brown Swiss showed evidence of heat-stress resistance in reproductive performance, relative to Holsteins. Longer calving intervals and older ages at first calving are not likely due entirely to effects of heat stress on fertility, but also to intentional extension of the voluntary waiting period to breed heifers or rebreed cows. Indirect evidence of heat abatement practices in some states was observed. Such practices can help reduce AFC and FCI, especially in regions with low humidity.

\section{ACKNOWLEDGMENTS}

The authors are grateful for financial support and data provided by AIPL, USDA. The senior author wishes to acknowledge partial financial support of Consejo Nacional de Ciencia y Tecnologia (CONACyT) Mexico. 


\section{REFERENCES}

Alnimer, M., G. De Rosa, F. Grasso, F. Napolitano, and A. Bordi. 2002. Effect of climate on the response to three estrous synchronization techniques in lactating dairy cows. Anim. Reprod. Sci. 71:157168.

Badinga, L., R. J. Collier, W. W. Thatcher, and C. J. Wilcox. 1985. Effects of climatic and management factors on conception rate of dairy cattle in subtropical environment. J. Dairy Sci. 68:78-85.

Barash, H., N. Silanikove, and J. I. Weller. 1996. Effect of season of birth on milk, fat, and protein production of Israeli Holsteins. J. Dairy Sci. 79:1016-1020.

Campos, M. S., C. J. Wilcox, C. M. Becerril, and A. Diz. 1994. Genetic parameters for yield and reproductive traits of Holstein and Jersey cattle in Florida. J. Dairy Sci. 77:867-873.

Castillo-Juárez, H., P. A. Oltenacu, R. W. Blake, C. E. McCulloch, and E. G. Cienfuegos-Rivas. 2000. Effect of herd environment on the genetic and phenotypic relationships among milk yield, conception rate, and somatic cell score in Holstein cattle. J. Dairy Sci. 83:807-814.

Correa-Calderón, A., D. Armstrong, Ray D., DeNise S., M. Enns, and C. Howison. 2004. Thermoregulatory responses of Holstein and Brown Swiss heat stressed dairy cows to two different cooling systems. Int. J. Biometeorol. 48:142-148.

Durr, J. W., H. G. Monardes, and R. I. Cue. 1999. Genetic analysis of herd life in Quebec Holsteins using Weibull models. J. Dairy Sci. 82:2503-2513.

Fox, D. G., and T. P. Tylutki. 1998. Accounting for the effects of environment on the nutrient requirements of dairy cattle. J. Dairy Sci. 81:3085-3095.

Graves, W. M. 2003. Improving dairy heifer reproductive management. Bulletin 1235. Cooperative Extension. University of Georgia, College of Agricultural and Environmental Sciences. Online. Available http://pubs.caes.uga.edu/caespubs/pubcd/B1234. htm. Accessed Dec. 14, 2004.

Jonsson, N. N., M. R. McGowan, K. McGuigan, T. M. Davison, A. M. Hussain, M. Kafi, and A. Matschoss. 1997. Relationships among calving season, heat load, energy balance and postpartum ovulation of dairy cows in a subtropical environment. Anim. Reprod. Sci. 47:315-326.
Kadzere, C. T., M. R. Murphy, N. Silanikove, and E. Maltz. 2002. Heat stress in lactating dairy cows: A review. Livest. Prod. Sci. 77:59-91.

Lopez-Gatius, F. 2003. Is fertility declining in dairy cattle? A retrospective study in northeastern Spain. Theriogenology 60:89-99.

Norman, H. D., T. R. Meinert, and M. M. Schutz. 1995. Age and seasonal effects on Holstein yield for four regions of the United States over time. J. Dairy Sci. 78:1855-1861.

Norman, H. D., R. H. Miller, J. R. Wright, and G. R. Wiggans. 2000 Herd and state means for somatic cell count from Dairy Herd Improvement. J. Dairy Sci. 83:2782-2788.

Oseni, S., I. Misztal, S. Tsuruta, and R. Rekaya. 2003. Seasonality of days open in US Holsteins. J. Dairy Sci. 86:3718-3725.

Pirlo, G., F. Miglior, and M. Speroni. 2000. Effect of age at first calving on production traits and on difference between milk yield returns and rearing costs in Italian Holsteins. J. Dairy Sci. 83:603-608.

Rajala-Schultz, P. J., and G. S. Frazer. 2003. Reproductive performance in Ohio dairy herds in the 1990s. Anim. Reprod. Sci. $76: 127-142$

Ray, D. E., T. J. Halbach, and D. V. Armstrong. 1992. Season and lactation number effects on milk production and reproduction of dairy cattle in Arizona. J. Dairy Sci. 75:2976-2983.

Ruvuna, F., B. T. McDaniel, R. E. McDowell, J. C. Johnson, Jr., B. T. Hollon, and G. W. Brandt. 1983. Crossbred and purebred dairy cattle in warm and cool seasons. J. Dairy Sci. 66:2408-2417.

Ruvuna, F., B. T. McDaniel, R. E. McDowell, J. C. Johnson, Jr., B. T. Hollon, and G. W. Brandt. 1986. Growth and reproduction characteristics of purebred and crossbred dairy cattle in first lactation. J. Dairy Sci. 69:782-793.

Tozer, P. R., and A. J. Heinrichs. 2001. What affects the costs of raising replacement dairy heifers: A multiple-component analysis. J. Dairy Sci. 84:1836-1844.

VanRaden, P., A. Sanders, M. Tooker, R. Miller, and D. Norman. 2003. Daughter pregnancy rate evaluation of cow fertility. Online. Available http://aipl.arsusda.gov/reference/fertility/DPR_rpt .htm. Accessed Feb. 5, 2004.

Wiggans, G. R., and P. M. VanRaden. 1991. Method and effect of adjustment for heterogeneous variance. J. Dairy Sci. 74:43504357.

Zwald, N. R., K. A. Weigel, W. F. Fikse, and R. Rekaya. 2003. Application of a multiple-trait herd cluster model for genetic evaluation of dairy sires from seventeen countries. J. Dairy Sci. 86:376-382. 